
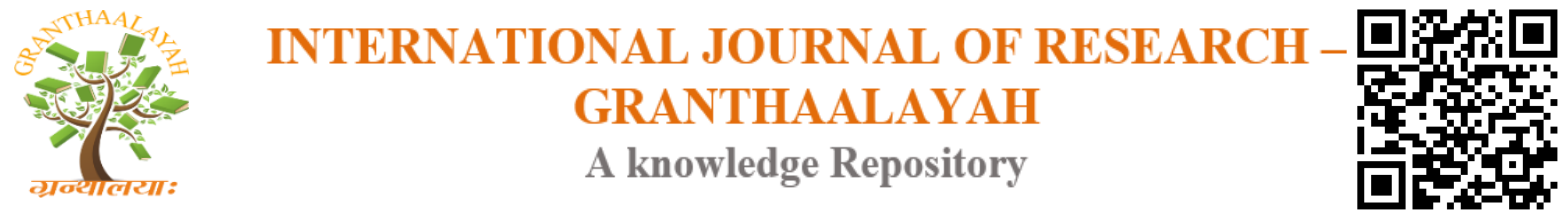

Science

\title{
PRELIMINARY SURVEY ON OCCURRENCE OF APHIDS, THRIPS LEAF MINER IN TOMATO GROWING AREAS IN MOROGORO REGION TANZANIA
}

\author{
Christopher L Materu *1, Essau W. Losujaki ${ }^{2}$ \\ ${ }^{* 1,2}$ P O Box 6226, Dar Es Salaam Tanzania
}

\begin{abstract}
Tomato (Lycopersicum esculentum L.) is one of the important crop in East Africa as a source of food, income and export. Occurrence of different pest including indigenous and alien in tomato fields are considered as a major threat pests to tomato growers. Worldwide pest problems in horticultural investment need to be considered carefully as their presence increase cost of production. Despite of this information in Tanzania there has been little research to update pest list infesting our tomatoes. The study was conducted in Morogoro region in Kauzeni and Bigwa wards whereby farmers grow different varieties of tomatoes. Farmers spray different fungicides and pesticides twice per week to manage different pests. The selected fields were located at $S$

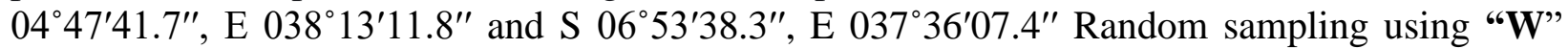
Pattern was used to get representation of the fields. Occurrence of pest population was estimated from ten plants during 2018/19, searching from young, middle and older leaves. Insect specimens were collected using fine forceps, aspirators, and preserved in ethanol $70 \%$ for laboratory identification.

The results showed no aphids were detected from frequent sprayed tomato fields, other pests observed include the white flies with mean (57) individuals per plant, followed by leaf miner (70) and the highest number was thrips representing (107) Mean population comparison showed a significant differences $\mathrm{P}<0.005$. Understanding occurrence of different pests in tomato growing areas could assist in planning sustainable Integrated Pest Management programme in tomato growing areas.
\end{abstract}

Keywords: Tomato; Aphids; Thrips; Leaf Miner.

Cite This Article: Christopher L Materu, and Essau W. Losujaki. (2019). "PRELIMINARY SURVEY ON OCCURRENCE OF APHIDS, THRIPS LEAF MINER IN TOMATO GROWING AREAS IN MOROGORO REGION TANZANIA." International Journal of Research Granthaalayah, 7(7), 1-5. https://doi.org/10.29121/granthaalayah.v7.i7.2019.675.

\section{Introduction}

Preliminary survey on occurrence of aphid, white flies, tomato leaf miner and thrips on tomato crop was carried in Morogoro Urban in Tanzania during cropping season 2019. The selected sites 
are suitable for horticultural crop production in the region. Tomato (Lycopersicum esculentum L.) is one of the important crop for smallholder farmers in East Africa as a source of domestic food and export markets (Grandillo et al. 1999). In Africa agricultural sector tomato is one of the most locally marketable vegetable (Anang et al. 2013). Apart from its nutritional value tomato production has a good employment opportunity both for youth and women.

Despite of its socio-economic importance tomato production in Tanzania is constrained by various factors including climatic factors, pests and diseases, post -harvesting and marketing. Pests are considered as a major constraint ie indigenous and alien species (Gray et al 2013; Paini et al., 2016). Pests including aphids, thrips and leaf miner are among of threat pests globally as they have ability to infest a wide range of cultivated and non-cultivated crops. Most of the damage is done by adult and nymphs through piercing plant tissues with their mouth parts. For example tomato leaf miner infest various plant parts including seedlings, flowers, tomato fruits and unsold fresh tomato fruits (Desneux et al., 2011), also infested fruits are small with low market value. Furthermore, aphids and tomato flower thrips are able to transmit destructive plant viruses in tomato and other family members of Solanaceae. Currently no studies has been carried out to determine economic losses caused by aphids flower thrips and tomato leaf miner in tomato production areas in Tanzania.

The intended study was carried out to document presence or absence of the threat pests and their associated natural enemies, from frequent pesticide applied tomato fields in Tanzania. Understanding occurrence of different threat pest species in tomato gardens could assist in developing sustainable pest management programs.

\section{Methodology}

Morogoro region is located along the coast belt 500m above sea level, and have a humid tropical climate with mean monthly temperatures between $25-27^{\circ} \mathrm{C}$. These districts receive a bimodal type of rainfall with growing seasons commence in March-June and short rain season SeptemberDecember. One of the selected survey areas was Kauzeni village located at S $06^{\circ} 53^{\prime} 38.3^{\prime \prime}$ and E $037^{\circ} 36^{\prime} 07.4^{\prime \prime}$ and the second one was Bigwa village located at $\mathrm{S} 06^{\circ} 47^{\prime} 56.4^{\prime \prime}$ and $\mathrm{E} 037^{\circ} 44^{\prime} 57.1^{\prime \prime}$ A total of twenty tomato fields were selected for the preliminary studies on common tomato pests. On each selected farm, ten plants were randomly selected from each tomato field. Data collection on aphids, white flies, tomato leaf miner and thrips occurrence, from each selected plant, was done by visual counting and collection of pest found feeding on the plant ie young premature leaves, middle age and old leaves. Sampling was carried out during morning hours from 9.00amm to 11 am when the insect were still inactive to migrate when disturbed. White flies, tomato leaf miner and aphids were collected using aspirators. Thrips samples were collected shaking the plants by doing so the pests were dislodged from the plant leaves or flowers to white plastic trays placed under each plant. Furthermore, samples were collected by using camel hair brush, all specimens were preserved into insect vials containing $70 \%$ ethanol well labeled for further laboratory work (Palmer et al. 1989; 1990). Sampled specimens were mounted and identified under a compound light microscope using the procedure described by Palmer (1990), at a magnification of 40. The Lucid key developed by Moritz et al. (2001) and the dichotomous keys adapted from Palmer et al. (1989; 1990). 
Pest management practices under small holder farmers were considered as the main factor that affect occurrence of different pest species in tomato production areas. Data from tomato fields were analysed using the GraphPad Instat computer programme version 3 to generate analysis of variance (ANOVA) and means.

\section{Results and Discussion}

The overall population mean of common pest sampled there was significant difference $(\mathrm{P}<0.0001)$ Furthermore population of aphids was not observed during sampling period as farmers do spray different pesticides mixed together without following any recommendations (Table1). Multi power -plus as fungicides and cutter as pesticide twice per week to manage different pest species. The population mean of common pests infesting tomato crop was 57 for the white flies, followed by leaf miner 70 and mean of 107 for the thrips respectively (Figure 1).

\section{Effect of Variety on Pest Occurrence on Tomato}

Most of the farmers were growing Assila F1, Zara, Imara and Kilele as their tomato varieties of choice. The most commonly used fungicide was Mutli -power plus mancozeb (Dithane M45) while the most commonly used insecticide was Cutter. None of the farmers use pesticide without combination of pesticide and fungicide or pesticide + pesticide (Table 1).

Table 1: List of common pesticide for insect pest and disease control

\begin{tabular}{|c|c|c|c|}
\hline Trade Name & Formulation & Common name & Usage \\
\hline Blast $60 \mathrm{EC}$ & EC & $\begin{array}{l}\text { Acetamiprid } \\
300 \mathrm{~g} / 1\end{array}$ & Control aphids on horticultural crops \\
\hline Karate 5EC & $\mathrm{EC}$ & $\begin{array}{l}\text { Lambdacyhalothrin } \\
50 \mathrm{~g} / 1\end{array}$ & $\begin{array}{l}\text { Control aphids, bollworms and sucking } \\
\text { bugs }\end{array}$ \\
\hline $\begin{array}{l}\text { Promectin } \\
1.8 \mathrm{EC}\end{array}$ & $\mathrm{EC}$ & Abamectin $18 \mathrm{~g} / 1$ & $\begin{array}{l}\text { Control bollworm, leaf miner and red } \\
\text { spider mite }\end{array}$ \\
\hline Cutter & & & Insect repellent \\
\hline
\end{tabular}

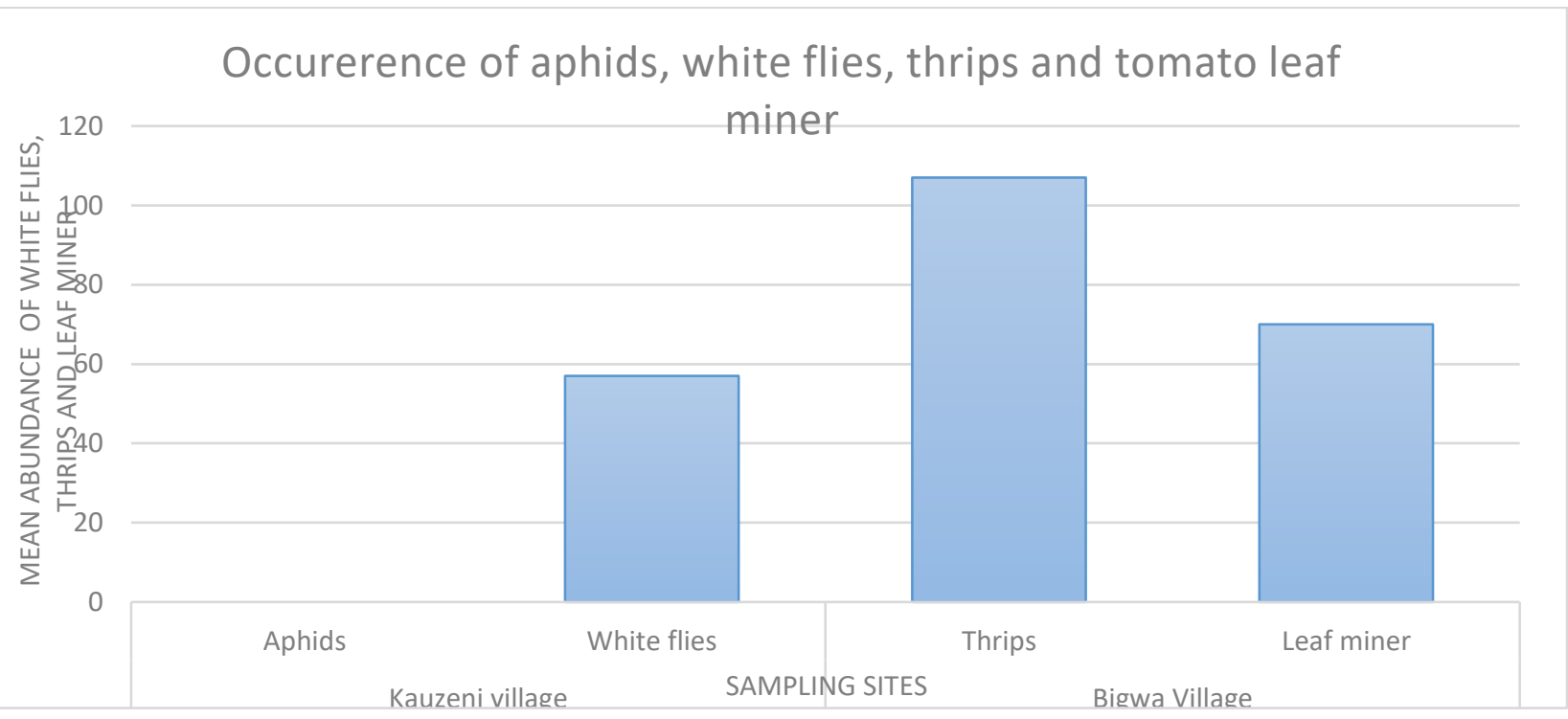

Figure 1: Occurrence of different pest species in tomato growing areas in Morogoro region 
Overall tomato yield production was low from multiple infested tomato fields probably due to ineffective pesticide application. No aphids were sampled from all fields probably combination of Blast, promectin, Karate and cutter was able to reduce the population from sampled fields. Population buildup of white flies, thrips and tomato leaf miner was the cause of low yield due to multiple infestation (Bliev et al.1985). Furthermore, population increase ie tomato leaf miner has reported to build resistant towards synthetic insecticides and reduced effectiveness of control (Lietti et al., 2005; Silva et al., 2011). Such outcome encourage tomato growers to opt for applying pesticide twice per week on their tomato fields (Reyes et al., 2012). Continuity application of pesticide on tomato growing areas to manage aphids, thrips, leaf miner and white flies make the situation worse and build up resistance (Silva et al., 2011; Reyes et al., 2012). To alleviate the situation use of integrated pest management strategies including cultural control, crop rotation, removal alternate hosts, destruction of crop residues and production of resistant tomato varieties, (Korycinska et al., 2009; De Oliveira et al., 2012). Integration of these strategies under tomato growing area will reduce pest problem.

\section{Conclusion}

Tomato provide a wide variety of nutrients required in human body, therefore tomato fruits production should be free from pesticides residues. Use of pesticides on management of aphids, thrips and leaf miner has raised problems on environmental side effects as well as human health. In order to reduce these problems need to carry out regular monitoring to detect damage symptoms, or presence of the pest (Graham-Bryce, 1981). The information will assist to establish economic threshold and decision making for pesticide use. Suitable time for pesticide application will assist to suppress reproduction rate of common pests under tomato production areas.

\section{Acknowledgements}

The research team would like to acknowledge Tanzania Agricultural Research Institute (TARI) Mikocheni, International Centre for Insect Physiology and Ecology (ICIPE) for their financial support, farmers and village leaders from the selected project areas for allowing research team to undertake this important study. Without support from this identified team members this work wouldn't be possible to be carried out.

\section{References}

[1] Anang, B.T., Zulkarnain Z.A. and Yusif S. (2013) Production constraints and measures to enhance the competitiveness of the tomato industry in Wenchi municipal District of Ghana. American Journal of Experimental Agriculture 3(4): 824-838

[2] Bliev U. K., Martynov A. N., Zarkov A. V. and Maximova L. I. (1985). Effect of Verpa preparation on the fertilityof soddy podzolic soil. Agrochimica 2: 97-100

[3] Desneux, N., Luna, M.G., Guillemaud, T. \& Urbaneja, A. (2011). The invasive South American tomato pinworm, Tuta absoluta, continues to spread in Afro-Eurasia and beyond: the new threat to tomato world production.Journal of Pest Science84: 403-408

[4] De Oliveira CM, Junior CV, Maluf RW, Neiva PI, Maciel MG (2012). Resistance of tomato strains to the moth Tuta absoluta imparted by allelochemicals and trichome density. Ciência e Agrotecnol. $36: 45-52$

[5] Graham-Bryce I. J. (1981). The behaviour of pesticides in soil. In The Chemistry of Soil Processes. (D. J. Greenland and M. H. B Hayes, ed.) John Wiley and Sons Ltd 
[6] Grandillo, S., Zamir, D. \& Tanksley, S.D. (1999) Genetic improvement of processing tomatoes: A 20 years perspective. Euphytica 110: 85-97

[7] Gray, Q., Abu, T. and Teddy, T. (2013). Tomato Production in Ethiopia Challenged by Pest. GAIN Report Number: 1305.

[8] Korycinska A, Moran H (2009). South American tomato moth (Tuta absoluta): plant pest factsheet. Sand Hutton, York, UK: FERA.

[9] Lietti MM, Botto E, Alzogaray RA, (2005). Insecticide resistance in Argentine populations of Tuta absoluta (Meyrick) (Lepidoptera: Gelechiidae). Neotrop. Entomol. 34:113-119

[10] Palmer JM. (1987) Megalurothrips in the flowers of tropical legumes: a morphometric study. In: Holman J, Pelikan J, Dixon AFG, Weismann L. (Eds). Population structure, genetics and taxonomy of aphids and Thysanoptera. The Hague (SPB Academic Publishing): 480-495.

[11] Silva GA, Picanco MC, Bacci L, Grespo AL, Rosado JF, Guedes RN (2011). Control failure likelihood and spatial dependence of insecticide resistance in the tomato pinworm, Tuta absoluta. Pest Manage. Sci. 67:913-920

\footnotetext{
*Corresponding author.

E-mail address: chrismateru@yahoo.com/ essau.losujaki@gmail.com
} 